\title{
Structural and Microbiological Analysis of Children's Pacifiers Served in Public Health Service and Nursery
}

\section{Análise Estrutural e Microbiológica das Chupetas de Crianças Atendidas em Serviços Públicos de Saúde e Creches}

\author{
Cristiane Coimbra de Paula*a, Louize Belém de Lima Barros ${ }^{\mathrm{a}}$; Jerry Luiz Sekia ${ }^{\text {; }}$ Rhayanne Edith de Assis ${ }^{\mathrm{a}}$; \\ Walkiria Shimoya-Bittencourt ${ }^{\mathrm{ab}}$
}

${ }^{a}$ Centro Universitário, Várzea Grande, Medicine School. MT, Brasil. MT, Brazil.

bUniversity of Cuiabá, Stricto Sensu Graduate Program in Environment and Health. MT, Brazil.

*E-mail: cristianepaula4@gmail.com

Recebido em: 19/10/2020

Aprovado em: 20/12/2020

\begin{abstract}
Despite the advances and advantages of breastfeeding, the non-nutritive sucking habit, especially that represented by the use of pacifiers, is still common in Brazilian children. It is estimated that two thirds of children will receive bottles and pacifiers at some point in the first year of life. The frequency of use and the possibility of contamination by harmful microorganisms may lead to the development of opportunistic infections affecting the children's health. The objective of the study was to conduct a microbiological and structural analysis of pacifiers for children treated in public services and daycare centers. A cross-sectional study was carried out with pacifiers for children aged 6 to 36 months. The collected pacifier was placed in a sterile individualized container and transferred to the laboratory for analysis. The children's pacifiers who are cared for in public health services and day care centers are contaminated not only the dirty ones but also the visually clean ones. The potentially pathogenic microorganisms found were mainly fungi and bacteria, Candida, Streptococcus and Pseudomonas, respectively.
\end{abstract}

Keywords: Pacifiers. Microbiology. Child Health.

\section{Resumo}

Apesar dos avanços e vantagens da amamentação, o hábito de sucção não nutritiva, principalmente o representado pelo uso de chupetas, ainda é comum nas crianças Brasileiras. Estima-se que dois terços das crianças receberão mamadeiras e chupetas em algum momento no primeiro ano de vida. À frequência de uso e a possibilidade de contaminação por microrganismos nocivos podem levar ao desenvolvimento de infecções oportunistas prejudicando a saúde das crianças. O Objetivo do estudo doi fazer análise microbiológica e estrutural das chupetas de crianças atendidas em serviços públicos e creches. Foi realizado um estudo transversal, com chupetas de crianças na faixa etária entre 6 a 36 meses de idade. A chupeta recolhida foi acondicionada em recipiente individualizado estéril e transferida ao laboratório para analises. As chupetas das crianças que são atendidas em serviços de saúde pública e creches estão contaminadas tanto as sujas quanto as visualmente limpas. Os microrganismos potencialmente patogênicos encontrados foram principalmente fungos e bactérias, respectivamente Candida, Streptocuccus e Pseudomonas.

Palavras-chave: Chupetas. Microbiologia. Saúde da Criança.

\section{Introduction}

The non-nutritive sucking habit, especially that represented by the use of pacifiers, is still common in Brazilian children. It is estimated that two thirds of children will receive bottles and pacifiers at some point in the first year of life..$^{3-5}$.

Besides causing early weaning, calming children, favoring sleep, among others ${ }^{6,7}$ pacifiers are considered a risk factor for the development of opportunistic infections, because children lack the maturation of immune barriers, and this non-nutritive sucking has the capacity to be a reservoir of microorganisms, especially by gram-positive bacteria, such as Streptococcus sp and Enterococcus sp. In addition, greater contamination of this sucking object usually occurs in children who are in intense contact with the soil, in families or caregivers who perform unsatisfactory hygiene or by the monthly non-replacement of this device ${ }^{4,8}$.

Despite the numerous benefits reported to the use of pacifiers, this device can still be considered as a vehicle for contamination and transmission of potentially pathogenic microorganisms such as bacteria and fungi. The frequency of use, the possibility of contamination by harmful agents, the importance for public health and the limited publication on the subject, it is important to know about the structural and microbiological pacifiers conditions. Therefore, the purpose of this study was to carry out a microbiological analysis of the pacifiers of children treated in health services and day care centers in the state of Mato Grosso.

\section{Material and Methods}

A cross-sectional study was outlined with the pacifiers of children attending health services and day care centers. Children aged between 6 and 36 months old who had a habit of pacifier sucking and who were consulted and who were in daycare centers participated in the study. Breastfed infants and preschool children who used the pacifier sporadically, and 
who had a cold or had oral infection were excluded from the study .

New pacifiers were offered to the participants in order to replace those included in the present study. The pacifiers were collected during the children's stay period at Várzea Grande Health Stations and day care centers in Cuiabá-MT. The collected pacifier was packaged in a sterile individual container and transferred to the microbiology laboratory.

The material was collected with the use of procedure gloves by means of sterile individual swab, moistened with saline solution of individual sterile flaconate. The swab was scrubbed clockwise four times around the nipple, repeating the procedure on the pacifier nipple/base seam. After collection, the pacifier was discarded. The swab was immediately stored in a test tube containing $10 \mathrm{ml}$ of Thioglycolate medium and then placed in the greenhouse for 1 hour for subsequent sowing on the plates containing culture medium.

After homogenizing the contaminated Thioglycolate samples, the Petri dishes were sown; those containing agar chocolate medium (CA), for viable bacteria growth, and those with Saboraud medium (SAB), for fungi growth. Such plates were numbered according to the number of the test tube containing the pacifier indication, corresponding to the material collected, for later identification during the counting of microorganisms present.

The samples were then incubated in a bacteriological oven at $35-37^{\circ} \mathrm{C}$, for 24 hours for the microorganism's growth. After the incubation period, the total number of colony forming units per milliliter $(\mathrm{CFU} / \mathrm{mL})$ of each evaluated microorganism was determined for each pacifier in the sample.

Since this research was carried out on inanimate objects, it was not necessary to submit the study to the Research Ethics Committee, however, the researchers requested authorization from Várzea Grande Health Stations and day care centers of Cuiabá-MT for data collection and parents' authorization to replace the pacifier used with a new one. The data obtained were tabulated in excel and after the measures of central tendency, dispersion and frequencies measurements were represented by tables.

\section{Results and Discussion}

Of the 32 pacifiers evaluated in this study, 19 (59.4\%) of the pacifiers belonged to the female sex and $13(40.6 \%)$ to the male sex.

The literature points out that a higher prevalence of the use of these utensils has been observed in boys, firstborn, low birth weight babies, who were not breastfed at the maternity hospital, those with families of lower age, lower educational level of caregivers and higher frequency of artificial foods consumption $^{3-5}$.

At the time of pacifiers donation, $18(56.3 \%)$ were dirty and $14(43.8 \%)$ were visually clean. Regarding the type of pacifiers nipple that were discarded, 26 (81.3\%) were orthodontic and $6(18.8 \%)$ were conventional. Regarding the pacifier's pacifiers material evaluated, 31 (96.9\%) were silicone and only $1(3.1 \%)$ were latex as described in Table 1.

Table 1 - Characteristics of pacifiers of children treated in Health and Day Care Services

\begin{tabular}{|l|c|c|}
\hline \multicolumn{1}{|c|}{ Variables } & $\mathbf{n = 3 2}$ & $\mathbf{\%}$ \\
\hline Pacifiers & & \\
\hline Girls & 19 & 59.4 \\
\hline Boys & 13 & 40.6 \\
\hline Dirty & 18 & 56.3 \\
\hline Clean & 14 & 43.8 \\
\hline Pacifiers nipple & & \\
\hline Orthodontic & 26 & 81.3 \\
\hline Conventional & 6 & 18.8 \\
\hline Pacifiers material & & \\
\hline Silicone & 31 & 96.9 \\
\hline Latex & 1 & 3.1 \\
\hline
\end{tabular}

Legend: \%: Percentage.

Source: Research data.

Similar to the findings of Silva et al. ${ }^{5}$ in their study, most pacifiers were also silicone pacifiers and most were dirty, although a few share them.

For the microorganisms evaluation, $100 \%$ of the 18 dirty pacifiers were microbial growth, $77.7 \%$ were coagulase negative Staphylococcus sp; $22.2 \%$ were Candidas sp.; 16.7\% were Streptococcus sp.; 11.1\% were Pseudomonas aeruginosa and Bacillus sp.; 5.6\% were Staphylococcus aureus, Klebsiella pneumoniae and Citrobacter freundii. In the 14 pacifiers apparently cleaned, 11 were really clean because there was no microorganism growth, confirming the importance of proper cleaning, however, in the other 3 there was microbial growth, $21.4 \%$ of which were negative staphylococci sp. Coagulase; 14.3\% Candida sp. and 7.1\% Citrobacter freundii (Table 2).

Table 2 - Microorganisms found in pacifiers of children treated in Health and Day Care Centers Services

\begin{tabular}{|l|c|c|}
\hline \multicolumn{1}{|c|}{ Type of Microorganism } & $\mathbf{n = 3 2}$ & $\mathbf{\%}$ \\
\hline Visually dirty pacifiers & 18 & 56.3 \\
\hline Coagulase-negative Staphylococcus & 14 & 77.7 \\
\hline Candidas sp & 4 & 22.2 \\
\hline Streptococcus sp & 3 & 16.7 \\
\hline Bacillus sp & 2 & 11.1 \\
\hline Pseudomonas aeruginosa & 2 & 11.1 \\
\hline Staphylococcus aureus & 1 & 5.6 \\
\hline Klebsiella pneumoniae & 1 & 5.6 \\
\hline Citrobacter freundii & 1 & 5.6 \\
\hline Visually clean pacifiers & 14 & 43.8 \\
\hline Coagulase-negative Staphylococcus & 3 & 21.4 \\
\hline Candidas sp & 2 & 14.3 \\
\hline Citrobacter freundii & 1 & 7.1 \\
\hline No micro-organisms & 11 & 78.6 \\
\hline
\end{tabular}

Legend: \%: Percentage.

Source: Research data.

Comina et al. ${ }^{9}$, observed that the two main isolated genera were also Staphylococcus and Candida; Silva et al. ${ }^{5}$ 
also found Candida and Streptocuccus, however mutans e Enterococcus sp type.

Pacifier is an object used by many children, resulting from a cultural habit of non-nutritive sucking. And for some time, it has been associated with negative effects related to the child's health, such as poor dental occlusion and otitis media. Its use is also related to colonization and infection by microorganisms. During the first years of life, children are more susceptible to opportunistic microorganisms, especially Candida sp., due to the immaturity of the immune system and because they are in direct contact with the environment and often do not receive adequate hygiene. In the present study, Candidas sp.,were found, both in dirty and clean pacifiers, such fact may be related to the high probability of being in the environment and the possible fecal-oral infection ${ }^{10-12}$.

Studies show that children receiving breast milk are less likely to be colonized by Candida albicans while it is twice as high in children using pacifier and bottle. In the studies in general, the children who make use of the night before sleeping, all day and all night can develop the microorganism because it is considered a humid, warm and dark environment $\mathrm{t}^{13,14}$.

Inadequate hygiene conditions allow the microorganisms proliferation that can be pathogenic to the child health, such as diarrhea, caries, associated with low immunity, which leads to an imbalance of oral microbiota, and opportunistic diseases may arise $\mathrm{a}^{15-17}$.

Thus, strict hygiene standards and an efficient protocol for cleaning pacifiers should be adopted to avoid contamination and alleviate parents' concern about the pacifiers safety and their children's health ${ }^{17,18}$.

\section{Conclusion}

The children's pacifiers who are cared for in public health services and day care centers are contaminated not only the dirty ones but also the visually clean ones. The potentially pathogenic microorganisms found were mainly fungi and bacteria, Candida, Streptocuccus and Pseudomonas, respectively. This instrument may be for sure related to some pathologies affecting children. The low level of knowledge and inadequate hygiene practices by caregivers are emphasized, so guiding actions to mothers such as lectures become interesting to improve the high contamination values.

\section{References}

1. Buccini GS. Evolução do uso de chupeta e sua influência no aleitamento materno exclusivo no Brasil. 1999-2008. São Paulo: Universidade de São Paulo; 2017.

2. Rigotti RR, Oliveira, MIC, Boccolini CS. Associação entre o uso de mamadeira de chupeta e a ausência de amamentação no segundo semestre de vida. Ciênc Saúde Coletiva 2015;20(4):1235-44. doi: http://dx.doi.org/10.1590/141381232015204.00782014 .

3. Silvério I. Consequências do uso prolongado de chupeta. Curitiba: Universidade Federal de Paraná; 2016.

4. Buccini GS, Benício MHDA, Venancio SI. Determinantes do uso de chupeta e mamadeira. Rev Saúde Pública 2014(4):57182. doi:10.1590/S0034-8910.2014048005128

5. Silva RM, Paula JF, Almeida-Marques RVD, Almeida LFD, Cavalcant YW. Análise estrutural e microbiológica de chupetas de crianças de creches públicas e particulares. Rev Cubana Estomatol 2014:51(1):1-11.

6. Cinar DN. The advantages and disadvantages of pacifier use. Contemp Nurse 2004;17:109-12.

7. Nelson AM. A comprehensive review of evidence and current recommendations related to pacifier usage. J Pediatr Nurs 2012;27:690-9.

8. Tomasi E, Victoria CG, Post PR, Olinto MTA, Béhague D. Uso de chupeta em crianças: contaminação fecal e associação com diarréia. Rev Saúde Pública 1994(5):373-9. doi: http:// dx.doi.org/10.1590/S0034-89101994000500011

9. Comina E, Marion K, Renaud FNR, Dore J, Bergeron E, Freney J. Chupeta: um reservatório microbiano. Nurs Health Scie 2006; 8(4)216-23.

10. Silva SREP, Andrade APRCB, Giunco A, Gonçalves CO, Pascutti EP, Carvalho MS, et. al. Análise quantitativa de microrganismos encontrados em chupetas. Com Scie Saúde 2009;8(1):57-64.

11. Carvalho FG, Parisotto TM, Hebling J, Spolidorio LC, Spolidorio DMP. Presence of Candida spp. in infants oral cavity and its association with early childhood caries. Braz J Oral Sci 2007;6(20):1249-53.

12. Lopes DF, Fernandes RT, Medeiro YL, Apolonio A, Morais C. Disinfection of Pacifier Focusing on Candida albicans. Clin Pediatr (Phila) 2019;58(14):1540-3. doi: 10.1177/0009922819875541.

13. Giugliani, E.R.J.; Problemas comuns na lactação e seu manejo. J Pediatr 2004;80:147-54.

14. Abreu PO, Grossi M, Hoerbe A, Santin LA, Silveira CB, Fernandes RD, et al. Análise da contaminação de chupetas por enteroparasitas e fungos em escola de ensino fundamental. J Health Biol Sci 2016;4(4):240-4. doi: http://dx.doi. org/10.12662/2317-3076jhbs.v4i4.697.p240-244.2016

15. Castilho SD, Rocha MAM. Uso de chupeta: história e visão multidisciplinar. J Pediatr 2009;85(6):480-9.

16. Festini F, Giusti F, Paoletti E, Biancalani L, Poggi GM. Is early use of pacifier a risk factor for diarrhea? Minerva Pediatr 2012;64(3):303-5.

17. Hernández LABS. Métodos de contaminação microbiana e desinfecção de chupetas. J Appl Oral Sci 2015;23(5):523-8.

18. Nelson-Filho P, Louvain MC, Macari S. Lucisano MP, Silva RAB, Queiroz AM, et al. Microbial contamination and disinfection methods of pacifiers. J Appl Oral Scie 2015;23(5):523-8. doi: https://doi.org/10.1590/1678775720150244 